\title{
The Mesquakie Memorial Feast
}

\author{
By William E. (BILl) Yeast
}

In October, 1961, Bill Yeast had the honor of being the first white man in many years to sit in on a Mesquakie Memorial Feast. This feast, an ancient Sac and Fox ritual held in observance of the dead, is usually taboo for outsiders, but Mr. Yeast was one of two exceptions in the past 100 years.

In doing research on Indians in and around Iowa, Yeast became a good friend of Chief Young Bear and his people on the Indian settlement near Tama. The following is an excerpt from a book the author is writing, Mesquakie, the Red Earth People, telling of the afore mentioned occasion.

On October 21st, I drove to the Indian settlement near Tama to visit my good friend George Young Bear and to take some pictures. While driving into the grounds looking for Young Bear, I saw six or eight dogs lying in the sun on the south side of the Mission. One of them recently had had a litter of pups and started to follow two little girls who were climbing a steep bank. About halfway up the hill was a small cave into which the children and the mother dog climbed. Presently, I saw one of the girls reach in and pull out a yelping puppy. The other child, using both hands, pulled out two more. Although Indian dogs are normally vicious, the mother dog didn't seem to mind the children's rough treatment.

Shortly, Young Bear came down the steps of the Mission with a smile on his face and approached with the remark, "Nice to see you, my good friend." He then suggested that I follow him home and we would visit.

We turned around and headed our cars for his cabin. Upon arriving there, a late model station wagon stopped across the lane approach. The driver, who was a big, good looking Indian about 40 years old, shouted something to Young Bear. He quickly walked up to the car and they talked in Mesquakie. I thought perhaps something was wrong since Young Bear was Chief, and they had come to get him to assist with the problem. After a moment or so, Young Bear called, "Bill, come here. I would like to have you meet Dewey Roberts." I did so. 
"Mr. Roberts wants us to come at once to his home. They are to have the Memorial Feast today for his brother, Ernest Roberts, who was killed by a train in June." I replied, "You mean you want me to go?" Young Bear answered, "Mr. Roberts wants you to attend."

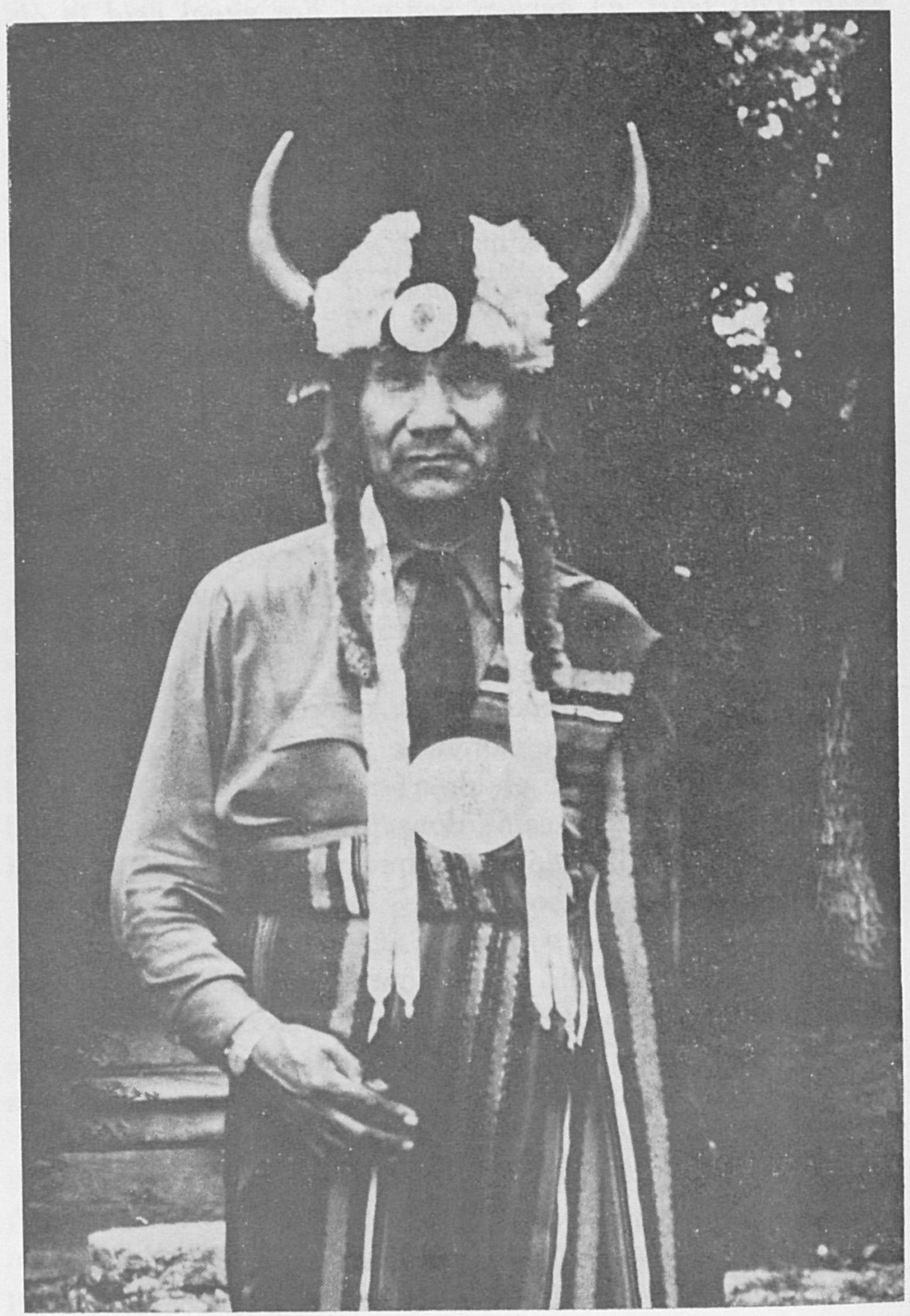

Chief Young BeAR 
This, I thought was unusual, in fact an honor for any white man to be asked to sit at a ceremony with his Indian Brothers. I thanked Mr. Roberts and accepted his invitation. (Dewey Roberts was cited for outstanding action in World War II and received the Purple Heart when wounded by German Machine guns at Cassino in Italy.)

As Young Bear and I rode to the ceremony, he briefly explained the Feast and the untimely death of Dewey's brother. There was much the Chief couldn't tell me about the feast. All I knew, was that it was to be a feast honoring Ernest Roberts who had died the previous June. What was to follow was like watching a foreign film in a language I did not know.

We passed the school and agency, and about one-half mile east came to a row of government houses. We turned into a drive which circled to the back of them. There, behind the second house, were 15 or more Indian men standing in small groups visiting. We got out and Young Bear introduced me to all of them.

At this point, Dewey Roberts, who had gone inside, came to the door and beckoned us in. I was told by Young Bear, to go first. I entered the back porch through the kitchen where there were eight or ten Indian women ranging in age from 15 to 50. As I came into the dining room, I noticed a long canvas spread on the floor extending from the north wall of the dining room to the south wall of the living room. It was about 40 feet long and five feet wide. On top of the canvas was a brightly flowered, clean piece of oil cloth which was covered with food of all description.

Young Bear told me to go down the left side of the canvas and stopped me at the exact center. Here there was a wicker chair, the only chair around the festive spread. He said I was to sit in the chair, so I did. Soon the men had seated themselves on the floor and the women and children had come in and taken their places. Since I was the only one in a chair I asked Young Bear if I couldn't sit on the floor like the rest. $\mathrm{He}$ answered, "You have the seat of our guest, but we would be happy for you to join us. We are used to sitting this way when we assemble, but thought you might become uncomfortable." I pushed the large chair back against the wall and 
squatted down beside him. This brought a smile of approval from several of the men.

There was very little noise or conversation. Suddenly White Breast, who was called upon to conduct the spiritual part of the ceremony, stood erect with his hands behind him, face upward, eyes closed and started to speak in Mesquakie. I noticed that everyone immediately bowed their heads, closed their eyes and sat in absolute silence. Occasionally I could catch a word, enough to know White Breast was speaking to Gitchie Manitou, the Great Spirit. (This is called a chant.) He prayed for what seemed like fifteen minutes or more. As he finished, the men all made a deep guttural moan and everyone raised their heads. Then, Young Bear looked at me and said, "Serve yourself, you are our guest and must dip first."

Directly in front of me was a large dishpan filled to the brim with what appeared to be pieces of wild duck and domestic fowl which had been stewed with squaw corn and pinto beans. There were four of these dishpans evenly spaced along the cloth. Also on the spread were large portions of Indian fried bread, broken into the equivalent of a half loaf of our bread, cakes, deep fried fowl and many bowls of native fruits. There was one large bowl which was heaped with quartered crab apples, grapes, sectioned plums, caramels, popcorn, and small pieces of jelly candies which had all been evenly tossed together.

I took the large ladle and dipped into the pan of meat in front of me. As soon as I set my bowl down, Young Bear said, "Now dip for me", and he extended his bowl toward the main dish. After I had served Young Bear, the others rapidly filled their bowls. No one made an attempt to serve himself until Young Bear and I had been satisfied. I noticed a young mother and father across from me took turns feeding their baby who ate everything they gave him, including the meat.

I also noticed several things uncommon to White Man's meals. There was little conversation, only the absolute necessary words being spoken, and there was salt on the spread, but no pepper. Spoons were the only utensils on the cloth, and although the Indian eats with his hands, he is very clean and graceful. He takes a boney piece of meat in his hand, and holding it by one end, strips the meat from the bone into 


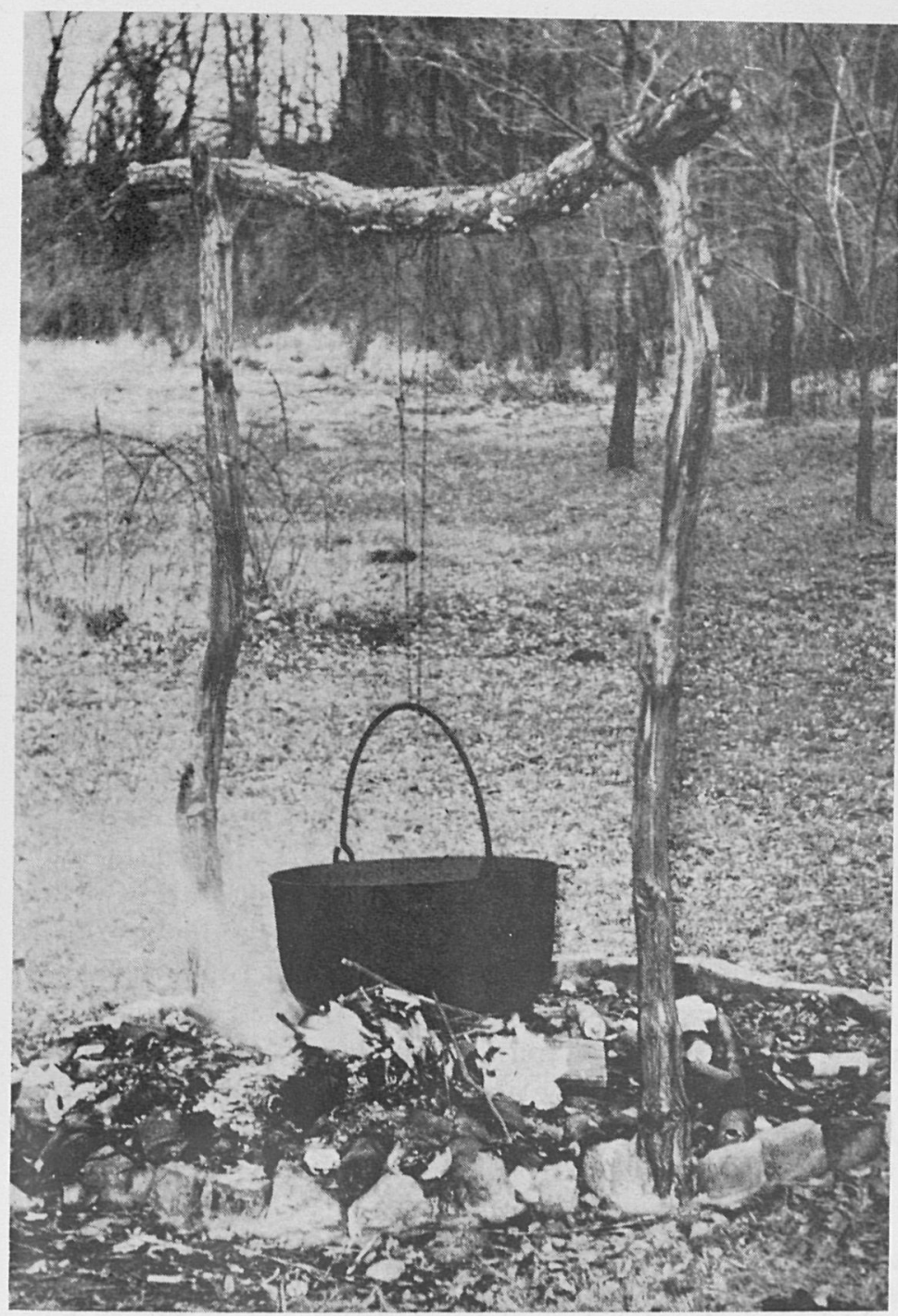

Typical Indian Community Kettle Used to CoOK the Ceremonial Meal.

the palm of the other and then eats from his palm. Sac and Fox food is cooked until it is exceptionally well-done and they eat everything they take, never wasting food.

When the stew was nearly gone, they started passing the 
apple mixture, pies and cakes. There were pumpkin, apple, berry and rhubarb pies and cakes of all sizes, shapes and color. These they also ate with their hands.

During the meal I noticed that beside my place, there was a large aluminum pan filled with what appeared to be clean water. When the last person had finished desert, Young Bear said to me in a low voice, "Pick up the pan, take a drink from it and pass it to me." I complied. He did likewise and passed it on to his right. Everyone, including the babies drank from the pan. When it had made the complete circle and had been set down by the girl on my left, Young Bear, pointing to the bowl of cigarettes in front of me, said, "Take a cigarette and match from the bowl, give me one and light both." This I did and he passed the bowl on to his right. Only the men and older women took the cigarettes, which I was later told was Sacred Tobacco. After this had made the rounds, White Breast again rose. With his eyes closed and face to the heavens, he spoke to Gitchie Manitou. This lasted about five minutes. When he finished, the men uttered the deep sound again, which I assumed was similar to our Amen.

There was a place set at the feast for the spirit of Ernest Roberts. When White Breast first spoke, he asked Manitou to return the spirit of the departed man to sit with us at the last earthly feast. After we finished eating, we drank of Life, "The Water" and smoked the Sacred Tobacco in tribute to Ernest Roberts. Then White Breast thanked Manitou and asked him to return his spirit to the Happy Hunting Grounds.

With this, the men got up and left the room. The children began carrying out the food and the younger women retired to the kitchen. In a matter of minutes the oil cloth and canvas were washed off and rolled up.

I returned with Young Bear to his home to visit briefly and say good-bye. While there, he gave me three Mesquakie dolls which were handmade by one of their women. These dolls, which are amazingly life-like, are made from scraps of buckskin and rags and beaded. The face profile on them is accomplished with one stitch. I learned that the few remaining women who produce these dolls are able to complete only four or five a year, so I cherish them dearly. They are excellent lent examples of the Indians' artistic abilities. 


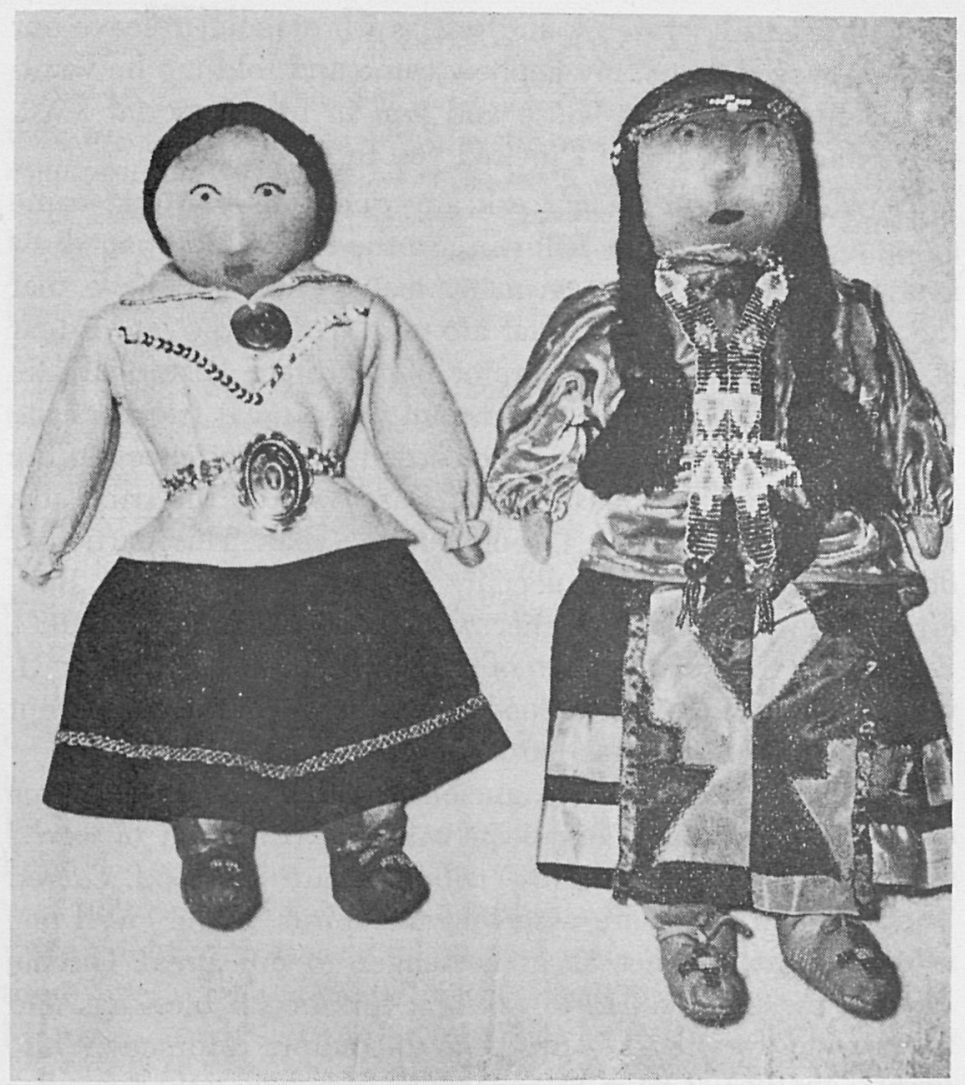

INDIAN DoLLS

I returned home in the early evening after thanking Young Bear for an unusual, but delightful day, and it was not until a few days later when I received a letter from the Chief that I knew what I had actually observed.

My Dear friend:

It is always wonderful having you come to visit with me and of course you always have to hunt me up all over the settlement, because, being Chief of our Sac and Fox Tribe I have many responsibilities and tribal functions I am required to attend or many times preside. I know you recall your visit October 21. It was wonderful to see an old friend for we have known each other for many years. We left the church at once to go to my house you have brought me some groceries of 
which I am truly grateful, and just as were about to leave our cars-Dewey Roberts, my nephew came and told me he wanted me to come to his house and join in his memorial feast, since you were with me I invited you to be my guest.

You did not hesitate nor ask any questions you just came along and do you know Bill you are the first white man to sit in at the memorial feast in many many years. I believe that the only other white man that ate with us was the late Edgar R. Harlan who was then curator of the State Historical Department of Des Moines. Mr. Harlan was a great friend of the Mesquakies and I suppose he recorded his experiences in the annals of Iowa. This feast or feasts are held by the tribe at a rate of twice per month throughout the year. This particular one you attended was especially in memory of Ernest Roberts, Dewey's younger brother who died last June 3rd, 1962. Ernest was the greatest hero of our tribe in the World War II, was in the Gen. Patton's Blood and Guts. General who swept through France and was hard to stop by the enemy.

The memorial feast is an ancient ritual so old that no one can tell the origin. It has been with the tribe and observed faithfully. The women of the tribe prepare the food. Sacred Tobacco, and water are used and the spirits of the loved one is called upon to act as a messenger to our great Gitchie Manito, the great spirit, to ask him for special blessings and to provide for all our needs and comfort. Horace White Breast, another of your Mesquakie friends, was asked to offer the chant and prayer. Horace is one of our chief spokesman. I wish I could cover every detail of the feast, the food. Preparing the ritual before the fires. The part of the fire, water, sacred tobacco, special sacred dish and all of it, but so regret I am a Mesquakie and hold these feasts as very sacred and meant only for those who believe like the Navajo, Pawnee, Blackfoot, Sioux and many other tribes.There are ever so many rites meant only for the Indians. I do believe and know that my people are feeling kindly towards you. Please Bill hold that as one of your lifes cherished possessions. Let me some day hear one of our elders say "He is our brother."

Please Bill come anytime, you are always welcome.

Your friend,

Chief Young Bear 
Copyright of Annals of Iowa is the property of State of Iowa, by \& through the State Historical Society of Iowa and its content may not be copied or emailed to multiple sites or posted to a listserv without the copyright holder's express written permission. However, users may print, download, or email articles for individual use. 